\title{
Policy dimensions of land-use change in peri-urban floodplains: the case of Paraty
}

$\underline{\text { José Barbedo }}^{1}$, Marcelo Miguez $^{2}, \underline{\text { Dan van der Horst }}^{3}, \underline{\text { Paulo Carneiro }}^{4}, \underline{\text { Philip Amis }}^{5}$ and $\underline{\text { Antonio Ioris }}^{3}$

\begin{abstract}
Peri-urban floodplains located in upstream reaches of urban areas play a key role in the resilience of social-ecological systems. The need to adapt to increasing flood risks by protecting these natural assets represents a huge challenge for many cities facing rapid expansion and limited financial resources for the mitigation of environmental impacts. To understand how better governance and management can be put in place, there is a need to map the key players shaping and/or being impacted by land-use change processes and assess the barriers keeping them from playing a more constructive role in the collaborative governance of cities, the natural resources which sustain them, and the environmental risks that pose a threat. A conceptualization of power regarding natural resource governance is presented and its implications for the relationships between actors and the many scales of decision making is discussed. Drawing on existing literature, we develop a heuristic framework for analyzing policy dimensions of land-use change processes, and reflect on the possible ways for key stakeholders to become over time more committed to and involved in a collaborative approach to the development of land use policies for urban flood prevention. We apply this framework to the Brazilian city of Paraty, a case study through which the recurring problem of flooding exposes the deepening tensions between conservation and development. Empirical results demonstrate the need to acknowledge the politicization of floodplain change and the importance of trying to bridge the gap between sectors and actors with conflicting interest in urban environmental management.
\end{abstract}

Key Words: adaptive management; Brazil; flood prevention; land-use adaptation; reflexive governance; water-flow regulation services

\section{INTRODUCTION}

In many peri-urban floodplains of the Global South, wetlands that have been previously converted for agricultural use are currently undergoing subsequent and more dramatic processes of land-use change. Uncontrolled urban development, especially in developing countries, led to a very fast process of urban growth into natural floodplains (Miguez et al. 2012) and cultural landscapes (Barbedo et al. 2014). This is particularly worrying in situations where the sprouting of low density residential areas in upstream wetlands aggravates flood risks in downstream urban districts (see Bullok and Acreman 2003). If cities are to be adapted to increasing flood risks (Kousky et al. 2011, Liao 2012, GFDRR 2012), a key challenge for urban water governance is to avoid the reproduction of these typical processes of land-use change, especially where important water-flow regulation services are provided. It requires not only the technical knowledge of what and where natural resources need to be preserved, but a deeper understanding of the root causes that lead to urban expansion regardless of the consequences of increasing exposure to flooding by downstream communities. It also involves a deeper consideration of the socioeconomic conditions and demands of groups living or working in the urban periphery and their daily struggles for political recognition. Those tensions characterize a highly politicized landscape and the imprint of socio-political disputes over a space marked by conflicts. The urban floodplain is, therefore, a highly contested terrain, which is the result of local socio-natural relationships that encapsulate past legacies and arrangements, as well as interactions happening at other scales, such as anthropogenic climate change. We reflect on these trends and tensions by situating socio-natural changes in peri-urban floodplains as a problem of political power within the warp of a complex interplay of interests, values, and demands.
Social-ecological changes and their governance, such as those related to urban development and floodplain protection, do not take place in isolation from political struggles. On the contrary, urban environmental change unfolds from a succession of deliberate efforts of transformation and appropriation of natural resources by the actors holding the bulk of political, economic, and cultural capital. In a society with marked social and economic differences, as in the case of postcolonial countries, localized disputes reflect and reinforce national circumstances and the wider balance of power. It is a "conflict between social groups developing differentiated modes of appropriation, use and meaning of territories ... in which the political subjects tend to impose on others their own projects for the environment" (Acselrad 1997, as cited in Carneiro 2004 [translated from the Portuguese]). This has been described as an exercise of hegemony in the Gramscian sense, as a distinctive geographical "project" that transforms spatial divides from a standpoint of the stronger sectors of society (Kipfer 2012). Within this context, the state is not a monolithic entity, but it is subject to multiple, contradictory influences and it is itself a politico-ecological player (Ioris 2014). This ambivalence opens the possibility that certain governance patterns undermine themselves by inducing changes that affect their own working (J. Voß and R. Kemp, unpublished manuscript). Discussions on reflexive governance take account of these unintended consequences (Voß et al. 2006), highlighting the endogenous nature of steering political actors (Rip 2006). Moreover, the formal powers of state institutions to adjust, adapt, and regulate the governance of natural resources is fragmented into several agencies, making these more vulnerable to domination of vested interests and the status quo in each particular sector. This study rises from these concerns, attempting to address the (in)ability of state actors, citizens, and interest

${ }^{1}$ Universidade Federal do Rio de Janeiro, COPPE/UFRJ, ${ }^{2}$ Escola Politécnica \& COPPE, Universidade Federal do Rio de Janeiro, ${ }^{3}$ University of Edinburgh, ${ }^{4}$ Universidade Federal do Rio de Janeiro, ${ }^{5}$ University of Birmingham, International Development Department 
groups in creating and nurturing a political space of action based on common values and aiming the sustainability of socialecological systems.

A key methodological question to properly analyze the policy dimensions of land-use change processes lies in departing from an adequate conceptualization of political power. Although it is also necessary to consider the relationships of control over some process or resource, such as the enforced protection of certain natural resources, we are interested in the more explicit sense of power as a capacity or dispositional property (Morris 2002), as an ability to effect outcomes, bringing about change in existing state of affairs. In critically analyzing the differences between transitive and intransitive power, Goehler (2000) explains that although transitive power refers to Weberian conceptions in terms of domination relationships, intransitive power has a selfreferential character based on the recognition of common values and collective action. From this angle, Arendt (1970:143) conceptualizes power as "the human ability not just to act but to act in concert." Parsons (1967:193) in turn, defines power as "the capacity of a social system to mobilize resources to realize collective goals." These conceptualizations may be described as intransitive forms of power, normatively charged with a sense of self-empowerment as a community (Goverde et al. 2000). Following this line of thought, we consider political power as the ability of citizens and its governance structures to promote certain agendas, secure specific interests, and achieve common goals within politico-cultural settings and according to given institutional constraints. This operational definition of power allows us to discern between the individual actions of the many structures of influence and the realization of a more politicized basis of environmental governance, with an implicit condition of cooperation and meaningful dialogue among stakeholders. Cooperative action is justified as an opportunity for shared learning and joint responses to collective problems, such as the conservation of ecosystem services of key importance for urban communities, the acknowledgement of socioeconomic inequalities, and concerted attempts to overcome political asymmetries. It is also an important component of transition into new patterns of socioeconomic activity and more inclusive and equitable cities.

Departing from the above theoretical considerations of power asymmetries that have an imprint on environmental change, we aim to gain insights into the process of urban expansion that runs counter to the safeguarding of water-flow regulation services and the conservation of floodplain areas. As such, we are not so much interested in explaining the current trend of urban expansion into peri-urban floodplains under the impact of conflicting interests and market forces, but to investigate the ways by which regulatory institutions contribute (or not) to the legitimization of trends and allow for the pursuit of sustainable alternatives. More specifically, we seek to answer the following questions: Who are the main players governing land and water resources and how do these influence land-use decisions? How do these different sectors interact with each other, contributing to certain outcomes regarding land-use change processes? What role do the actions and nonactions of the state at their various levels of governance play in the reproduction of processes of suburbanization into peri-urban floodplains? By searching for answers to these questions, we intend to critically discuss the decision-making process and the consequences of action or inaction for the satisfaction of social-ecological demands.

\section{DESCRIPTION OF THE STUDY AREA}

We have chosen the Brazilian case study of Paraty for its relevant ecological characteristics, but also because of its historical and cultural importance, all of which fit nicely with the very factors that give rise to our questions. The city has been built at sea level, while mountain river systems flowing into the floodplains bring rapid discharges of large volumes of storm water into this area when heavy rains occur. Paraty is one of the thousands of Brazilian towns and cities experiencing "urban environment transition" (McGranahan and Haughton 2006) whereby rapid urban growth is not yet supported by appropriate natural resource management. Brazilian urban population has dramatically increased in the last fifty years, from $45.08 \%$ in 1960 to $84.4 \%$ in 2010 (IBGE 2010), a significant proportion living in large metropolises and megacities, which is a common Latin American trend. The accelerated process of urban growth is reflected in an "adaptation deficit" (Quan and Dyer 2008), that is, a lack of capacity to adapt to increased environmental risks, even without considering climate variability and change.

The city of Paraty (Fig. 1) was founded in the 17th century by the Portuguese. It was strategic location because of the ancient indigenous path across the Atlantic Forest into the hinterland, used by the colonizers during the gold rush in Minas Gerais. In the 19th century, it became an important regional center and port area and the historical town was planned and built by the Portuguese military engineers (see Cury 2008). In 1966 Paraty was declared a National Cultural Heritage site and today it is a candidate for UNESCO World Heritage. The recognized value of its built heritage and cultural landscape makes the problem of urban flooding an (even more) important threat. Furthermore, a significant part of the municipal territory is considered an environmental protection area ( $83 \%$ of the municipal area), covered by remnants of the Atlantic Forest. Therefore, in addition to historical heritage, the city also has an important environmental heritage, and its relatively long history of attempting to protect its immediate surroundings furnishes the advantages of historical perspective.

Figure 2 shows the evolution of urban expansion in Paraty in the last 50 years. It has approximately 20,000 inhabitants in the urban area and demographic growth has been accelerated in the last three decades, with a $27 \%$ increase in population in the last ten years (IBGE 2010). From 1985 onward, pressures over land resources have been more intensely manifested through emergence of low-density residential areas, multiplication of formal and informal settlements in flood risk areas, and deployment of urban subdivisions. All of these factors have contributed to socially inequitable and environmentally unsustainable patterns of urban growth, while housing deficit, especially among the poor, remains problematic.

Previous studies based on hydrological modeling of the PerequêAçu and Mateus Nunes river basins, where the city of Paraty is located, conducted by Barbedo et al. (2013) have shown that expanding the city into upstream reaches of the floodplain is likely to increase urban flooding into the historical town. This analysis has demonstrated that the continuity of the current trend of urban expansion will bring a considerable rise in peak levels, which owes both to the decrease in natural retention areas and increased runoff conditions. In a subsequent study, Barbedo et al. (2014) explored an alternative scenario of urban development and 
indicated potential hydrological benefits of adopting a more compact urban form using the remnant open spaces located in downstream areas of the floodplain. Relying on the conclusions of these previous studies, the current research aimed at understanding the institutional and political barriers for the adoption of hydro-ecological recommendations and for a better integration of urban development and environmental conservation policies.

Fig. 1. Regional location of Paraty.

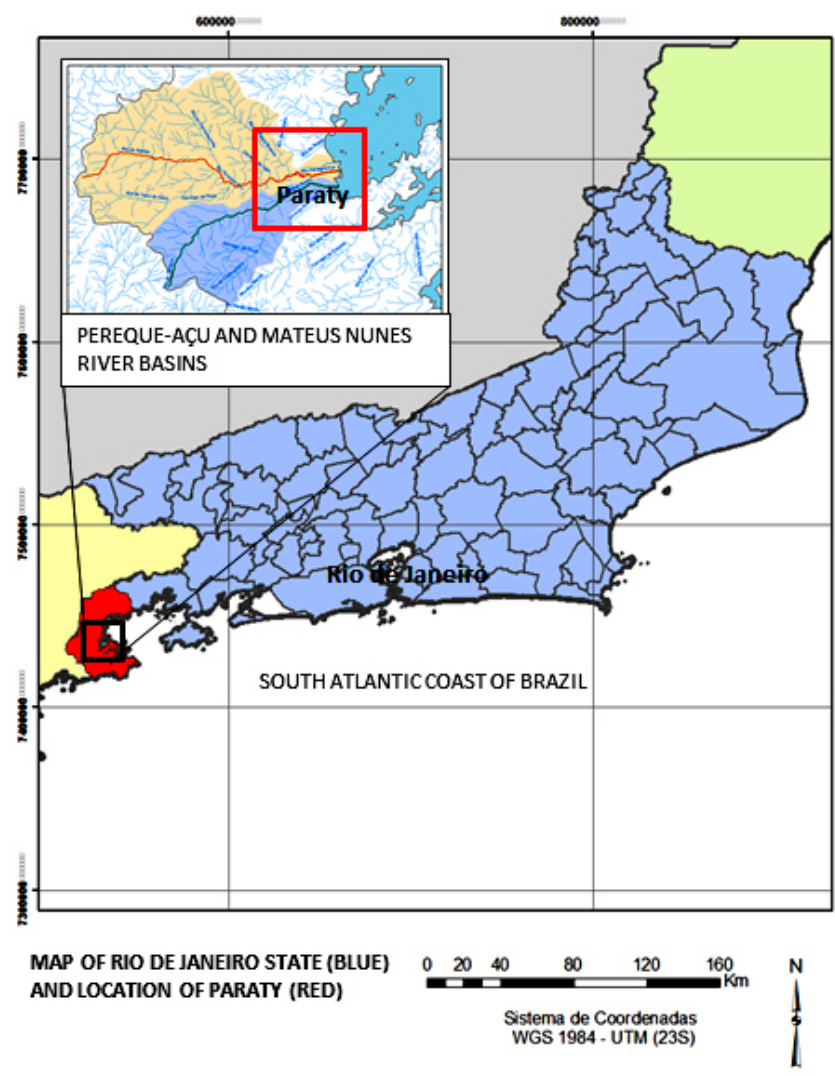

\section{METHODOLOGY}

The study required the use of qualitative and quantitative research methods. Empirical data for this paper was obtained through a combination of secondary data analysis, semistructured interviews, focus groups, and direct observation of deliberation processes. This was complemented by a desk study of the legal and political context concerning land-use planning and water management. Participation of the first author of this paper in a workgroup for discussing the Master Plan of Paraty, organized by the municipality between February 2013 and July 2014, yielded important inside perspective on related decision-making processes and highlighted the relevance of the various issues under analysis here. Key actors have been interviewed following a snowball approach, starting at public hearings where key actors were represented. Anonymity was guaranteed to all participants. This allowed us to identify stakeholders in the early stage of the research and subsequently to identify a broader range of actors. A desk-based study of official reports provided input for the
Fig. 2. Urban growth in Paraty 1960-2010. Original sources: compilation of aerial and satellite photos and Google images build in a GIS platform.
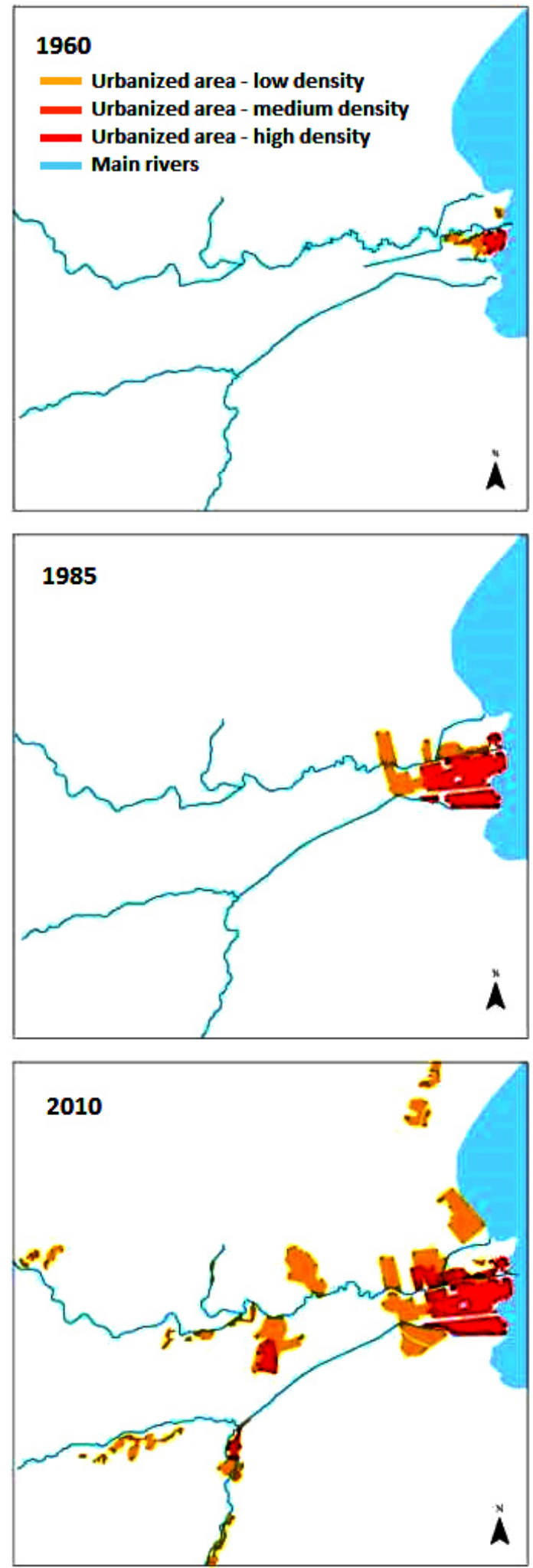
preparation of the interview questions, and broadened the scope of the data collection exercise. A guideline with a set of interview questions addressed the different ways parties perceive how land should be used, grasping causal relationships on dysfunctions and conflicts regarding land use. Interviews were semistructured to allow us to expand into other topics emerging during the course of the questioning. In total 29 semistructured interviews were held covering a wide range of actors, from officeholders and organization representatives to residents affected by flooding. The data collected from interviews were triangulated through focus groups with representatives of the main sectors involved, i.e., housing market and construction business, tourism industry, environmental associations, and technical experts. Different topics were grouped in a new developed typology based on the number of times each type of interest had been mentioned in the interviews.

To analyze distinct political dimensions of land-use change processes we adapted an existing heuristic framework on reflexive governance (Voß and Bornemann 2011). This framework consists of a 3 × 3 matrix whereby policy, polity, and politics are organized at micro, meso, and macro levels of governance. There are two added attractive aspects in applying this framework to this study because in the Portuguese language one can use the word "Políticas" for all three meanings: "policy," "politics," and "polity." Concerning the three levels considered in this framework, it is particularly appropriate in this context because Brazil is a federal republic with three layers of public administration: municipal, state, and federal. The structure of the framework has been applied to organize the information gathered in the study. We have adapted it to fit the focus of our analysis, reducing the number of variables in the framework. The policy aspects have been separated into two different formats: although identified problems are presented and discussed at length, solutions are not formulated as reasoned proposals. These are only indicated in the conclusions as potential tactics to overcome identified barriers for improved governance. Concerning polity dimensions, key institutional actors and relevant legal instruments have been discussed within this framework. The politics of land-use decisions is also discussed, focusing on identified barriers for improved governance concerning land-use decision processes and related interactions among stakeholders.

To validate the information obtained from interviews and focus groups, analyzed according to the framework mentioned, we also conducted public presentations and open debates about land-use change and urban flooding with key actors. These discussions took place in Paraty between November 2013 and February 2014, allowing us to engage with the different sectors about the expected flood impacts of further urban expansion into upstream reaches of the floodplain, as well as potential hydrological benefits of alternative scenarios of urban development. Finally, a second round of interviews allowed us to specifically investigate the changing, or resistant, perceptions and positioning of each actor regarding urban flooding, ability and potential willingness of key stakeholders, as expressed in the interviews and focus groups, to become over time more committed to and involved in a collaborative approach to the development of land-use policies for urban flood prevention. Inquiring about stakeholders' perceptions is justified because perceptions are the best forms of assessment available when factual measurement is not possible
(Bressers 2011). This last phase of the research allowed us to rank the level of interest each actor manifestly has on urban flooding (low, medium, or high). Interest was considered as the level of importance urban flooding-related problems represent to each stakeholder before and after the discussion. High interest means that the actor is fully committed to consider flood related concerns on land-use decisions; medium interest means that the actor attributes reasonable importance to flood related problems, that is, (s)he considers these concerns but these are not a priority; low interest means the actor manifestly neglects flood-related problems.

\section{RESULTS}

To facilitate the analysis of the results, we assessed the antagonistic forces at play in the decision-making process, as well as the dominating discourses of key stakeholders; we focused on how flood risks were perceived by stakeholders and to what extent these were taken into account, both at the collective and individual level. Results of the application of a heuristic framework helped to synthesize the policy, polity, and politics of the empirical study, considering the micro, meso, and macro levels of governance.

At the state level, the State Institute of Environment (INEA) is formally the most influential organ on far-reaching land-use decisions. INEA is the result of the fusion of three different environmental organs: the State Foundation of Environmental Engineering (FEEMA), the State Superintendence of Rivers and Lagoons (Serla), and the Forest State Institute (IEF). This fusion represented an effort to integrate water resources and the management of the territory and forests, and is a deliberate attempt to overcome the traditional lack of collaboration between these organs. INEA regulates urban operations requiring environmental permits and is part of the National System of Conservation Units (SNUC). According to the information gathered with staff members, this agency has access to resources and skills, but still lacks the strategies and political ability to effectively implement land-use adaption measures. A senior staff member of INEA reported that their potential steering role is often undermined by the difficulty in collaborating at the local level, contributing to a degree of mistrust among government institutions, which often see one another as adversaries instead of partners. When asked why INEA does not have a stronger role in promoting preventive measures for flood prevention, this official responded that much of what INEA is supposed to do is overwhelmed by the acute needs of high-risk areas, which calls for more hard-engineering infrastructure.

In addition to INEA, other public agencies have a stake in landuse decisions. The analysis of the discourse of federal agencies such as the National Institute for the Artistic and Historic Heritage (IPHAN), responsible for the cultural heritage, and the Environmental and Natural Resources Agency (IBAMA), reveals that both agree on the need to preserve the remnants of Atlantic Forest along the hills that surround the city of Paraty, but urban expansion into upstream reaches of the floodplain is not seen as a concern to these agencies. After the revision of the master plan, IPHAN has taken prompt action against a municipal proposal of extending the urban expansion area without proper public deliberation, and succeeded in bringing this issue to the Public Ministry, which in turn embargoed the proposal. However, IPHAN's main concern is the conservation of the built heritage 
and protecting the old town from visual impacts whereas IBAMA's issues are related to biodiversity conservation and protecting the mountains from human influence. Both agencies have access to resources and have developed strategies according to their mandates, but do not possess the skills and political will to address issues related to urban flooding. As an example, on the public consultation sessions of the new master plan of Paraty, both representatives of IPHAN and IBAMA advocate a "gradient of occupation" in which the low-lying areas that make the transition between the city and the mountains should be preferably occupied in favor of the protection of the hillsides. We directly asked representatives of IPHAN if they would incorporate in their land-use regulation guidelines specific recommendations regarding urban flooding. The answer was that flood prevention is not within the mandated responsibilities of these agencies. Interviews conducted with technical staff of both agencies have shown that even though flood prevention may be recognized as a cobenefit to environmental and cultural heritage conservation and biodiversity, IPHAN and IBAMA have their own priorities, and flood prevention is not a program focus of these agencies. The contributions of IPHAN held in public audiences about the revision of the master plan, as well as specific legislation issued by these organs is centered on limiting the urban density of new settlements and the maximum height of buildings, while the consequences of converting agricultural lands located upstream from the existent urban area is apparently ignored.

When applying the heuristic framework, it was possible to identify the main groups of interest, which are able to exert hegemony, through action or inaction, over the management of floodplain and urban change. The low level of effective commitment of the municipality in urban flood problems is reflected in existing regulations at the local level: the municipal law 609 of 1981 (Prefeitura de Paraty 1981) regulates land-use operations in the municipality, on which article 15 states that land subdivision in flooded areas or areas subject to flooding are not allowed before action has been taken to assure the drainage of water. This short reference is a transcription of the federal law 6766/89 and does not bring any further specification; the "flooded areas" are not formally mapped by the municipality. In an interview, a staff member argued that although urban expansion toward upstream areas could aggravate floods in the consolidated urban area, these consequences may be mitigated by the use of hard engineering solutions. This is an example of how the faith in hard mitigation measures to resolve the problems of inadequate location of new neighborhoods reflects a poor understanding of the externalities produced by the progressive anthropization of hydrologic systems.

Beyond the public sectors, other local actors have shown common difficulties on reaching a common understanding of the consequences of urban expansion into upstream reaches of the floodplain. Short-term economic goals have been a common feature in the discourses of these actors, as well as the scarcity of available land for urban development. The majority of local actors, when asked about their interests, were very prominently concerned with short-term economic goals (mentioned 52 times in the interviews), varying from "job creation," "making a profit," or "opening new businesses," to less specified definitions such as "local development" and "economic growth." According to many of these respondents, conservation areas restrict local development against people's interests. Landowners and real estate representatives were unanimous in expressing their disappointment with the difficulties they face in developing their property portfolios. The common hope expressed by landowners and other real estate agents is that the new expansion area defined by the new master plan will finally enable the municipality to release construction permits on their lands, favoring urban expansion and further urban development in the surrounding areas of Paraty. Real estate sector respondents explained that land price increases in the remnant areas available for development close by the city, is fuelling speculation of the land market and urban expansion.

As a consequence, the conversion of rural areas for urban use is preferred by economic groups and individuals operating in the construction business, especially in a context of tourism and recreation as in Paraty. According to a former municipal officer presently retired, these groups often exert pressure on the elected councillors responsible for the approval of land-use decisions and municipal plans. This respondent also stated that "the aldermen seek to satisfy a variety of private interests in exchange for previously attained political agreements." This may be confirmed by the fact that in each new administration, land-use decisions are often pushed by the municipal council, and it is often difficult to distinguish in the words of local politicians between private and the public interests regarding urban expansion. A clear example of the dominance of short-term economic goals within local politics is provided by the attempt to alter the expansion area (extended to the maximum height of $100 \mathrm{~m}$ above sea level) stated in article 189 of the Master Plan under revision by article 208 in 2002 (maximum height of $200 \mathrm{~m}$ ). As already mentioned, this proposal was embargoed by the Public Ministry after IPHAN's intervention. A representative of the former municipal secretary of urbanism and the environment (SEDUMA), mentioned during the interview the difficulty of proceeding with land tenure and regularization of urban land within the mandated period of four years. According to this respondent, the required legal processes are not fulfilled within this period because of the high level of inertia built into state organizations. As a consequence, mandated politicians have little interest and motivation to follow a coherent municipal urban policy with longterm perspectives.

Examining public hearing sessions about the Master Plan of Paraty, large landowners have shown little interest in participating in open discussions, even when the land-use decisions are supposedly highly relevant to their interests. During interview, a large landowner in Paraty pointed out a number of constraints on developing on his land, which has already been classified by the municipality as an urban expansion area. The property owner complained about the lack of clear criteria and guidelines for licensing and long bureaucratic procedures. Noteworthy, this large property owner has shown a growing interest in urban flooding; this is a clear example of how a major player can understand the potential of looking beyond the limits of its direct interests, enabling the pursuit of solutions with a more holistic perspective. Medium-sized and small property owners seem to have considerable willingness to influence land-use decisions at the local level; however, for this last group it is more problematic to determine their degree of influence because most respondents reported a variety of outcomes regarding their intentions to 
Table 1. Heuristic framework for analyzing political dimensions of land-use change in Paraty, Brazil (adapted from Voß and Bornemann 2011).

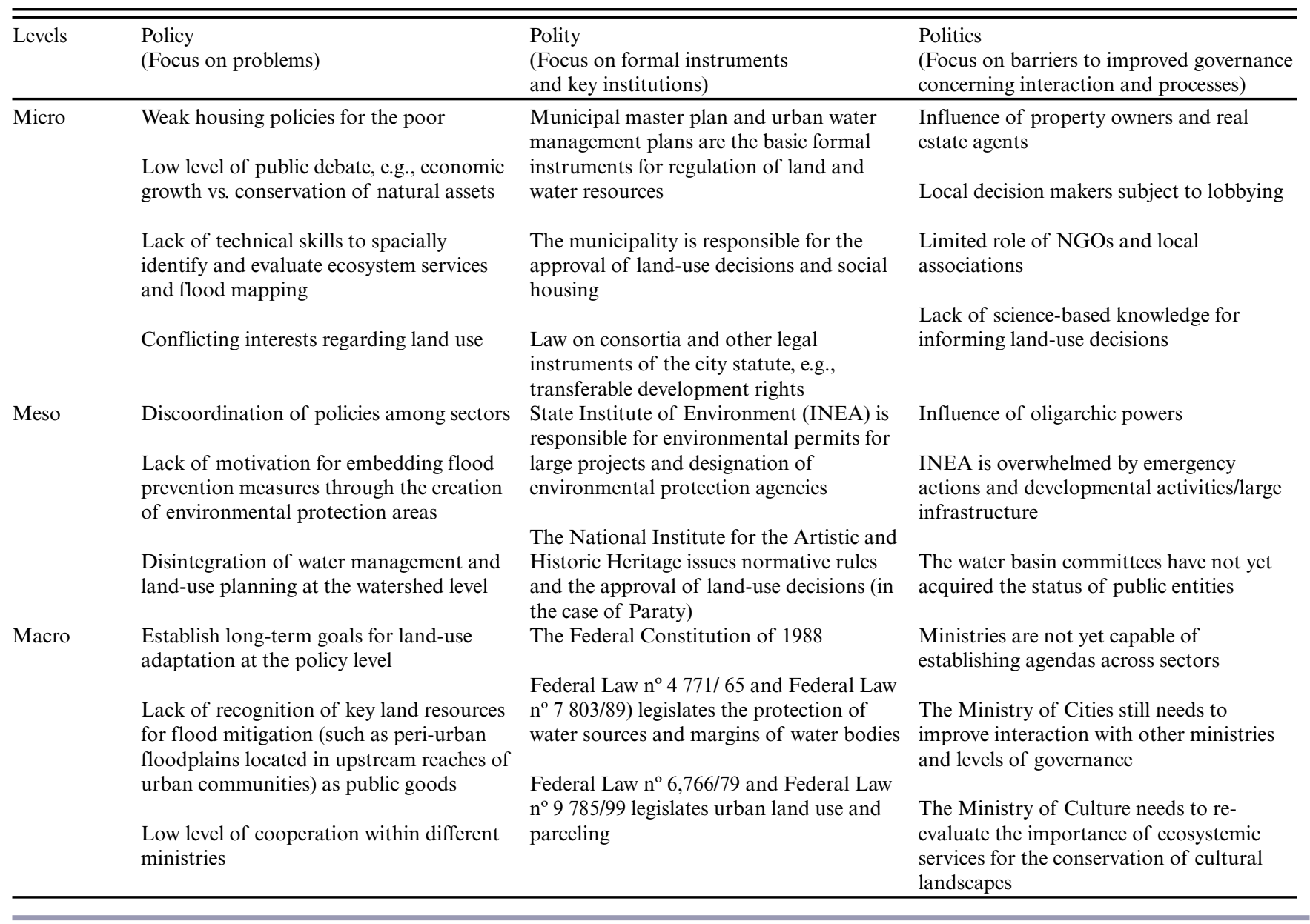

develop their land. The piecemeal actions of the informal market exert strong influence on land-use change processes. Informal sections of the housing market compete through various speculation processes and act directly in the territory, contributing to increasing fragmentation of land ownership. Along the river banks in upstream regions of the basins, settlements, hotels, lodges, and restaurants flourish and end up competing for land with the local population, pushing the poor into even more vulnerable areas, subject to landslides, where most casualties are registered after flood events. Interviews conducted with residents affected by floods have shown that the informal sector emerges as a response to the lack of affordable housing and land tenure security for economically disadvantaged social groups.

Concerning other organized sectors of the civil society, such as NGOs and local associations, none of these organizations had specific activities directed toward flood related problems faced by local communities, indicating a low interest in urban flooding. However, organizations represented in public participation processes have shown high interest after the discussion of the expected impacts of urban expansion on flooding. Establishing a concrete causal link between urbanization in a particular upstream location and the flooding externalities experienced by the residents of particular downstream areas helped actors to understand the effects of their future actions, linking more directly those who may cause the aggravation of flooding to the victims of flooding events. Willingness to influence land-use decisions has substantially increased during public hearings. Among the interviewed residents affected by flooding before and after the public hearings, the change of perception of the causal relations between ongoing land-use change processes was significant: the lack of interest in land-use decisions has been recognized as a lack of awareness of the externalities produced by these. Table 1 shows the ability to exercise power on land-use decisions by the various institutions and organizations with a stake in land use decisions.

Table 1 encapsulates the key elements of study organized according to the heuristic framework (after Voß and Bornemann 2011). It can be seen that the aspects analyzed spread through different scales of interaction and are translated into the policy, polity, and politics dimensions within this framework. To fit the focus of our analysis, we reduced the number of variables as described in the methodology. The Table limits the focus on policy problems identified in our results. Regarding polity dimensions, key institutional actors and relevant legal instruments have been 
summarized. Politics of land-use decisions focus on the identified barriers for improved governance concerning land-use decision processes and related interactions among stakeholders.

\section{DISCUSSION}

The findings of this study suggest that competing interest groups influence land-use decisions by formal and informal means, and all take part in the production of territorial changes that vividly incorporate relations of power. Our analysis lends support to Röling's (1997) assertion that urban governance requires a soft system, i.e., a space or platform that facilitates learning among stakeholders by sharing, and validating, their understanding of the situation to reach consensus. However, the outcomes of open discussions and deliberative processes also indicate that participation alone is not enough to remove established political imbalances, confirming that policy changes have to go in line with institutional changes (Größler 2010). Previous urban studies in Paraty have already advocated for the need to create a web of institutional relationships within continuous collaborative processes toward common goals (Munhoz 2003). Mapping stakeholders and observing the deliberation processes enabled the deconstruction to some extent, but only partially, of how actors exert their influence and attempt to get their particular view established as the "common view" (Voß and Bornemann 2011). Local government seems to be too beholden to hegemonic interests and constrained by the demands of the electoral cycle. Landowners seek to legitimize their projects through piecemeal decisions, a typical strategy of economic agents in cities under a framework of governmental regulation that is very incomplete and subject to manipulation (Devas 1999). Among these, economic forces shape local housing markets for land development while local lobbying takes place in the grey areas between state and society, often prevailing over the public interest of securing water-flow regulation services.

Our findings corroborate that what actually happens is the result of a myriad of individual, market-based decisions combined with long established relations of influence, which can be traced back to centuries of colonialism. This reminds us that individuals and organizations involved in decision-making processes have selfinterests that they want to achieve and that need to be taken into account in negotiation processes (Größler 2010). In fact one of the main constraints for responsible public authorities in effectively incorporating concerns about urban flooding on their political agenda is the impact of private interests whose main concern is to use their influence to their own benefit, mainly in the short term. In particular, the supposed role of the elected councillors to defend the public interest seems to be distorted by the mechanics of electoral processes. The registered episode of an attempt to alter the urban expansion area with the agreement of elected councillors (and prompt action from IPHAN against this attempt, resulting in the Public Ministry's embargo of the correspondent municipal law) indicates the possibility of loyalty of some of these local actors to specific local interests, becoming enablers of capitalist speculation processes. It is noteworthy that Arendt observed that the organization of active citizenry capable of collective action can be used against the state apparatus (Arendt 1960), by exerting a growing influence on bureaucratically alienated representative powers, and forcing these powers to take adequate account of societal and environmental interests.
The effective political power to actively pursue concerted solutions to pressing problems is not prioritized by decision makers, while the conservation of floodplains is seen as a constraint on the local economy by individuals with high stakes in land-use decisions, but also by municipal officials and other influential groups. Although short-term economic benefits are not compared with long-term costs, such disruptive practices lead to an increasing spiral of public investment, requiring the coverage and maintenance of infrastructure and services. These dilemmas show that the actors involved are not able to reach a common understanding of development problems, making it difficult to resolve contradictions between different perspectives and contentions. That is particularly relevant in a situation, such as Paraty, where there are significant power asymmetries between, on the one side, landowners and real estate interests, and on the other, weak government agencies, NGOs, and wider society. Such difficulties may be explained by what Habermas (1970) has called a "systematically distorted communication," referring to situations in which the communicative abilities of the actors involved in a certain socio-political context do not allow mutual understanding of common problems. Another important question raised by the interviews, is that some of the actors with higher stakes in land-use decisions choose not to talk in public discussions, avoiding open confrontation by simply refusing to make public his or her interests and intentions, thus endangering the possibility of developing clear and fair deliberation processes.

One main problem for implementing land-use adaptation measures for flood prevention is the institutional biases of different sectoral views. In previous studies, Miguez et al. (2012), noted that the most urgent and complex task of the agenda of public managers who are really committed to building a sustainable future for cities is to promote the integration of public policies concerning water resources, sanitation, and urban land use. Indeed, the integration of different sectoral perspectives is a difficult endeavor because most initiatives to promote intersectorality face a number of endemic challenges due to specific complexities in each public policy area (Wojciechowski 2009). The results reveal that each agency is mainly concerned with their specific agenda, which in turn, are also constrained by limited access to land resources and housing needs. Conservationists such as IPHAN are concerned with avoiding further development close to the extant built heritage, limiting urban density and maximum height of new buildings, whereas environmentalists such as IBAMA give top priority to protecting the remnants of the Atlantic Forest. The lack of articulation between the rules imposed by these institutions, together with weak integration with other pressing needs (such as housing for the poor and flood prevention) are contributing, paradoxically, to further urban expansion into upstream reaches of the floodplain and encroachment into river banks, and, therefore, putting the historic and environmental heritage under a greater risk.

Because the fusion of the institutions that gave place to INEA was precisely justified by the need to better articulate the management of land and water resources, this state level organ should be more proactive in promoting the integration of different sectoral views and concerns. Nonetheless, the actions of INEA are notoriously contained by stronger government agencies involved in the promotion of resource exploitation, e.g. oil, urban 
development, and infrastructure expansion (see Ioris 2012). A stronger focus on promoting proactive measures of land-use adaptation for flood prevention is required, because this agency is in a better position for designating environmental protection areas when adequate. It is important to note that the regulation of environmental protection areas is not only applicable for biodiversity conservation purposes, but can also be created to assure sustainable uses for the welfare and security of urban communities in strategic locations. The idea of applying these instruments for flood prevention is nonetheless a very new initiative regarding peri-urban catchments in the Brazilian context, but it is also very topical because a recent innovative experience in this regard is being developed in "Baixada Fluminense," in the Metropolitan Area of Rio de Janeiro (see Carneiro et al. 2012).

There are a number of legal instruments in Brazil regarding land tenure arrangements and compensation measures for landowners when the public interest is at stake. The City Statute (see Barros et al. 2010) presents a set of key innovative instruments that may well be used for these purposes. These instruments allow for the separation of property rights from the potential rights of construction, they foresee the transmission of surface rights, and include the right to pre-emption. Such possibilities offer an interesting potential for change in the current state of affairs, but because these are not easily enforced, decision makers are not motivated to use those instruments. Taxation mechanisms may also prove to be useful in regulating the land market, controlling speculation processes, and promoting the economic use of land and water resources. Urban density patterns need to be properly examined, finding an appropriate balance between the availability of land resources and housing demands within the municipality. In this regard, Porto and Lobato (2004, as cited in Correia 2005) noted that an adequate articulation of command and control instruments, social participation processes, and more flexible negotiation and regulation mechanisms are crucial. In the face of the complexity of the decision-making processes concerning land use, none of these can produce efficient results in isolation; they need to complement each another. It has been observed in recent literature on flood management in Brazil that the institutionally embedded decentralization paradigm has contributed to an excessive localism (Carneiro 2008), while land-use decisions at the local level are generally highly fragmented rather than seen holistically. It is important to note that the Brazilian Constitution, although allocating significant responsibilities to municipal authorities, also creates confusion between different layers of public administration and competition for resources. That situation has direct consequences for water and land-use management. The literature on natural resource management frequently presents cases in which greater local control did not lead to greater sustainability or justice (Purcell and Brown 2005), which can be explained because of the barriers and constraints caused by the political asymmetries that prevent the production of meaningful changes.

Bringing flood related problems into the public arena of debate and raising awareness of the implications of urban expansion on flooding is in itself a positive outcome of this study. A lesson learned during this exercise is that it is not only necessary to effectively identify and map flood prone areas, but it is also necessary to effectively communicate and engage in the local scene where land-use decisions are being discussed, increasing the chance of incorporating these concerns in zoning regulations. To increase awareness on the impacts of disruptive practices, relevant ecosystem services evidence, including ecosystem valuation, is required at the municipal level where many planning and policy decisions affecting ecosystems take place (Holzinger et al. 2014). There is a long way to go between turning a specific socioenvironmental issue into a legitimate object of political debate and the uptake of these issues by responsible political authorities. The competing interests described earlier may well constitute serious opposing power forces so that these issues may never turn into legislative proposals and binding decisions. In such cases, entitlements of new housing developments granted by local governments in flood prone areas may jeopardize coherent urban water management plans, meaning past approvals and projects may need to be reconsidered. When issues defying the status quo are deliberately left out of the political agenda, this often leads to processes that Bachrach and Baratz (1962) called "nondecisionmaking," that is, a decision not to make a decision.

\section{CONCLUSIONS}

Following the operational definition of power adopted in this study, the current trend of natural resource depletion in periurban floodplains may be explained by a contingency of powerlessness. Examining land-use decisions in a specific politico-cultural setting, allowed for the identification of the difficulties of citizens and their governance structures in promoting flood prevention measures to secure water-flow regulation services from which the welfare and security of this community depends. In this case, we have shown that concerns about biodiversity conservation, forest protection, and cultural heritage have not been interwoven into a coherent development strategy, nor have the actions of the mandated institutions for these concerns been capable of protecting specific ecosystem services that are critical for the safety and well-being of urban residents. The adoption of generic rules through bureaucratic procedures ends up being part of the problem, ultimately favoring the reproduction of low-density residential areas and an everexpanding consumption of land resources, consequently aggravating flood risks. Arguing that the reproduction of these processes reflects the difficulties of existing formal institutions in exercising their legitimate power does not mean state institutions are useless or rendered meaningless. On the contrary, the point is rather that the dispositional power of these institutions rests in their untapped potential capacity to promote strong coalitions toward certain agendas, securing specific interests of key players to achieve common goals. As long as state agencies do not unlock this potential, these are prone to domination and strategic instrumentalization by the hegemonic interference of the stronger groups of interest. Such contingency is contributing not only to undesirable environmental outcomes, but is also contrary to the very interests of each of the respective participants.

At the heart of these questions lies the current lack of recognition of the public interest of certain land resources by local, regional, national, and even global levels of governance. It is particularly important to understand that water-flow regulation constitutes unique, nontransferable ecosystem services and produces benefits to many, but does so through a geographically uneven distribution. Once we acknowledge that the safety and well-being of downstream communities and the resilience of natural systems 
ultimately depend on the benefits produced by ecological processes within each watershed, the management of these territories can no longer be defined by the sum of private interests and socioeconomic pressures, but must take full and formal account of negative externalities when these represent a threat to the community as a whole. The case of Paraty, as a candidate city for World Human Heritage and containing unique hydroecological features, provides a clear example of both local and global common interest in halting the current trends toward unsustainable urban expansion.

The key importance of land-use adaptation on urban water governance is an eloquent example of the need for innovation in rethinking public policy. It requires political commitment across a range of agencies that may not traditionally have had the technical capacity, political experience, and organizational culture to develop effective collaborative partnerships toward long-term common goals. Embedding innovative governance practices requires the consolidation of inclusive and lasting coalitions between state agencies and universities, focused on the production of knowledge from a holistic perspective of specific socio-natural realities. Developing hypothetical scenarios that take implementability into account may be instrumental in attracting key actors, but special care must be taken to avoid perverse effects of interest-driven distortions. More than imposing solutions, leading actors should facilitate open-minded communication among stakeholders, by promoting integrative science-based learning processes in new transition arenas.

Responses to this article can be read online at: http://www.ecologyandsociety.org/issues/responses. php/7126

\section{Acknowledgments:}

José Barbedo gratefully acknowledges funding by the Foundation for Support of Research in the State of Rio de Janeiro (FAPERJ, ref: 100-223/2014)

\section{LITERATURE CITED}

Arendt, H. 1960. Vita activa. Kohlhammer, Stuttgart, Germany.

Arendt, H. 1970. On violence. Allen Lane, London, UK.

Bachrach, P., and M. Baratz. 1962. The two faces of power. American Political Science Review 56(4):947-952. http://dx.doi. org/10.2307/1952796

Barbedo, J., M. Marins, M. Miguez, and M. Sousa. 2013. Análise dos impactos da expansão urbana nas inundações em Paraty, com uso do modelo de células MODCEL. XX Simpósio Brasileiro de Recursos Hídricos (SBRH). Bento Gonçalves, Rio Grande do Sul, Brazil.

Barbedo, J., M. Miguez, D. Van der Horst, and M. Marins. 2014. Enhancing ecosystem services for flood mitigation: a conservation strategy for peri-urban landscapes? Ecology and Society 19(2): 54. http://dx.doi.org/10.5751/ES-06482-190254

Barros, A., C. Carvalho, and D. Montandon. 2010. Commentary on the city statute. Puliccompleta, São Paulo, Brazil.
Bressers, N. 2011. Co-creating innovation - a systemic learning evaluation of knowledge and innovation programmes. Dissertation. Erasmus University of Rotterdam, Rotterdam, The Netherlands.

Bullok, A., and M. Acreman. 2003. The role of wetlands in the hydrological cycle. Hydrology and Earth System Sciences 7 (3):358-389. [online] URL: http://hal.archives-ouvertes.fr/ docs/00/30/47/86/PDF/hess-7-358-2003.pdf http://dx.doi.org/10.5194/ hess-7-358-2003

Carneiro, P. 2004. Dos Pântanos à escassez: uso da água e conflito na baixada dos Goytacazes. Centro de Documentação e Informação do Pólis Instituto de Estudos, Formação e Acessoria em Políticas Sociais. Annablume Editora, São Paulo, Brazil.

Carneiro, P. 2008. Controle de inundaçoes em bacias metropolitanas, considerando a integraçao do planejamento do uso do solo a gestao dos recursos hídricos. Dissertation. Federal University of Rio de Janeiro, Rio de Janeiro, RJ, Brasil.

Carneiro, P., A. Cardoso, G. Zampronio, and M. Martingil. 2012. A gestão integrada de recursos hídricos e do uso do solo em bacias urbano-metropolitanas: o controle de inundações na bacia dos rios Iguaçu/Sarapuí, na Baixada Fluminense. Ambiente e Sociedade 13(1).

Correia, F. 2005. Algumas reflexões sobre os mecanismos de gestão de recursos hídricos e a experiência da união europeia. REGA 2(2):5-16. [online] URL: http://www.abrh.org.br/sgcv3/ UserFiles/Sumarios/4ae7f60c1e7de44f9399b97a06318b64 4b1dda8e8532502fcb34aad37da6ce69.pdf

Cury, I. 2008. O estudo morfológico de Parati, no contexto urbanístico das cidades maritimas atlânticas de origem portuguesa. Faculdade de Arquitetura da Universidade de São Paulo, Brazil.

Devas, N. 1999. Who runs cities? The relationships between urban governance, service delivery and poverty. Urban Governance, Poverty and Partnerships Theme Paper 4, International Institute for Environment and Development, Department for International Development, London, UK.

Global Facility for Disaster Reduction and Recovery (GFDRR). 2012. Cities and flooding: a guide to integrated urban flood risk management for the 21st century. World Bank Washington D.C., USA. [online] URL: https://www.gfdrr.org/gfdrr/urbanfloods

Goehler G. 2000. Constitution and use of power. Pages 41-59 in H. Goverde, P. Cerny, M. Haugaard, and H. Lentner, editors. Power in contemporary politics: theories, practices, globalizations. Sage, London, UK. http://dx.doi.org/10.4135/9781446219935. $\underline{\mathrm{n} 2}$

Goverde, H., P. Cerny, M. Haugaard, and L. Howard. 2000. Power in contemporary politics. Sage, London, UK.

Größler, 2010. Policies, politics, and polity. Systems Research \& Behavioral Science 27(4):385-389. http://dx.doi.org/10.1002/ sres. 1051

Habermas, J. 1970. On systematically distorted communication. Inquiry 13(1-4):205-218. [online] URL: http://www.tandfonline. com/doi/abs/10.1080/00201747008601590 http://dx.doi. org/10.1080/00201747008601590 
Holzinger, O., D. Van der Horst, and J. Sadler. 2014. Citywide ecosystem assessments: lessons from Birmingham. Ecosystem Services 9:98-105. http://dx.doi.org/10.1016/j.ecoser.2014.05.003

Instituto Brasileiro de Geografia e Estatística (IBGE). 2010. Censo 2010. IBGE, Brasilia, Brasil. [online] URL: http://www. censo2010.ibge.gov.br/

Ioris, A. A. R. 2012. Applying the strategic-relational approach to urban political ecology: the water management problems of the Baixada Fluminense, Rio de Janeiro, Brazil. Antipode 44 (1):122-150. http://dx.doi.org/10.1111/j.1467-8330.2011.00848. $\underline{\mathrm{x}}$

Ioris, A. A. R. 2014. Environmental governance at the core of statecraft: unresolved questions and inbuilt tensions. Geography Compass 8/9:641-652. http://dx.doi.org/10.1111/gec3.12155

Kipfer, S. 2012. City, country, hegemony: Antonio Gramsci's spatial historicism. Pages 83-103 in M. Ekers, G. Hart, S. Kipfer, and A. Loftus, editors. Gramsci: space, nature, politics. Wiley, Chichester, UK. http://dx.doi.org/10.1002/9781118295588.ch4

Kousky, C., S. Olmstead, M. Walls, A. Stern, and M. Macauley. 2011. The role of land use in adaptation to increased precipitation and flooding: a case study in Wisconsin's Lower Fox River Basin. Resources for the Future, Washington, D.C., USA. [online] URL: http://www.rff.org/RFF/Documents/RFF-Rpt-Kousky $\% 20$ etal $\%$ 20GreatLakes $\% 20(2)$.pdf

Liao, K. 2012. A theory on urban resilience to floods-a basis for alternative planning practices. Ecology and Society 17(4): 48. http://dx.doi.org/10.5751/ES-05231-170448

McGranahan, G., and G. Haughton. 2006. Urban ecologies. Environment and Urbanization 8(1):3-8. http://dx.doi. org/10.1177/0956247806063938

Miguez, M., A. Veról, and P. Carneiro. 2012. Sustainable drainage systems: an integrated approach, combining hydraulic engineering design, urban land control and river revitalisation aspects. Pages 21-54 in M. S. Javaid, editor. Drainage systems. In Tech, Rio de Janeiro, Brasil. [online] URL: http://cdn.intechopen. com/pdfs-wm/30387.pdf

Morris, P. 2002. From power: a philosophical analysis. Pages 278-303 in M. Haugaard, editor. Power: a reader. Manchester University Press, Manchester, UK.

Munhoz, M. 2003. A Revitalização dos Espaços Públicos de Borda D’Água em Paraty. Thesis. Universidade de São Paulo, FAU-USP, São Paulo, Brasil.

Parsons, T. 1967. Sociological theory and modern society. Free Press, New York, New York, USA.

Prefeitura de Paraty. 1981. Lei Municipal 609/1981. Prefeitura de Paraty, Paraty, Brazil.

Purcell, M., and J. Brown. 2005. Against the local trap: scale and the study of environment and development. Progress in Development Studies 5:279-297. [online] URL: http://pdj. sagepub.com/content/5/4/279. short http://dx.doi. org/10.1191/1464993405ps122oa

Quan, J., and N. Dyer. 2008. Climate change and land tenure: the implications of climate change for land tenure and land policy. Food and Agriculture Organization of the United Nations, Rome, Italy. [online] URL: ftp://ftp.fao.org/docrep/fao/011/aj332e/aj332e00. pdf

Rip, A. 2006. A co-evolutionary approach to reflexive governance, and its ironies. Pages 82-100 in J. Voß, D. Bauknecht, and R. Kemp, editors. Reflexive governance for sustainable development. Edward Elgar, Cheltenham, UK. http://dx.doi. org/10.4337/9781847200266.00013

Röling, N. 1997. The soft side of land: socio-economic sustainability of land use systems. ITC Journal 3/4:248-262.

Voß, J.-P., D. Bauknecht, and R. Kemp, editors. 2006. Reflexive governance for sustainable development. Edward Elgar, Cheltenham, UK.

Voß, J.-P., and B. Bornemann. 2011. The politics of reflexive governance: challenges for designing adaptive management and transition management. Ecology and Society 16(2): 9. [online] URL: http://www.ecologyandsociety.org/vol16/iss2/art9/

Wojciechowski, M. 2009. Inter-institutional mechanism for collaborative governance: a case study of the local management group in the formation of the regional consortium: Mulheres das Gerais. Prepared for the Congress of the Latin American Studies Association, Rio de Janeiro, Brazil. Centre for Human Settlements, University of British Columbia, Vancouver, British Columbia, Canada. [online] URL: http://www.chs.ubc.ca/ consortia/outputs3/LASA2009-Wojciechowski John.pdf 